\title{
THE NEXUS BETWEEN PRICES, EMPLOYMENT AND OUTPUT GROWTH: A GLOBAL AND NATIONAL EVIDENCE
}

\author{
Guglielmo Maria Caporale ${ }^{1}$, Marinko Škare² \\ ${ }^{1}$ Centre for Empirical Finance, Brunel University, West London UB8 3PH, UK. \\ ${ }^{2}$ Faculty of Economics and Tourism "Dr Mijo Mirković", Juraj Dobrila University of Pula, \\ Preradovićeva 1/1, 52100 Pula, Croatia \\ E-mails: ${ }^{1}$ guglielmo-maria.caporale@brunel.ac.uk; ${ }^{2}$ mskare@efpu.hr (corresponding author)
}

Received 09 December 2013; accepted 01 March 2014

\begin{abstract}
This paper investigates how output growth, employment growth and inflation influence each other in the short/long run. It builds on Phillips (1962) and Blanchard Fischer (1989) assessment that empirical links between output, employment and prices are central issue in modern macroeconomics. This paper brings a global perspective on short and long term links between employment growth, inflation and output growth using panel cointegration framework with non-stationary heterogeneous panel (119 countries over 1970-2010). The empirical results (on global and national level) strongly support the existence of a long-run equilibrium relationship between output growth, employment growth and inflation. A central finding is that possible trade-off effects between growth, employment and prices varies significantly among economies. Therefore, universal answers to questions Is inflation good for growth or Is there a trade-off between employment and growth are not straightforward for general macroeconomic theory. Each country must design own economic policy (targeting) taking into account the quantitative relationships between growth, employment and prices. This has important policy implications also for price setting policies, cost management, market strategy and risk management through productivity-demand disturbances effects on the business environment.
\end{abstract}

Keywords: inflation, output growth, employment-growth, panel cointegration tests, nonstationary heterogeneous panels, productivity-demand disturbances, business environment.

Reference to this paper should be made as follows: Caporale, G. M.; Škare, M. 2014. The nexus between prices, employment and output growth: a global and national evidence, Journal of Business Economics and Management 15(2): 197-211.

JEL Classification: C23, E24, E31, E60.

\section{Introduction}

Knowledge of the linkages between employment growth, inflation and output growth is essential for designing policies not resulting in "overshooting" or "undershooting" of the targeted "equilibrium", as well as for choosing optimally the particular inflation rate, level of economic activity or "natural rate of unemployment" that should be targeted. Further, it might also be instrumental in reducing economic cycles. 
In two famous studies Phillips $(1958,1962)$ analysed the relationship between unemployment and the rate of change of nominal wages in the United Kingdom and that between employment growth, inflation, and output growth. Studies identifying negative inflation-growth link find variability of inflation to be harmful for growth. Price volatility discourages investments and lowers production efficiency lowering future profitability through uncertainty. In condition of low investments and rising prices balance of payments becomes a real problem. Several studies support the thesis that inflation is harmful for growth. Bruno and Easterly $(1996,1998)$ find a negative correlation for inflation and growth with high price volatility (40\%). Burdekin et al. (2004) find that inflation is harmful to growth in industrialised countries only when the price level hits $9 \%$, whilst the threshold is $3 \%$ in the developing economies. López-Villavicencio and Mignon (2011) supply strong evidence of a non-linear negative link between inflation and growth with a threshold effect. Other studies highlight positive impact of inflation on growth through real interest rate - long run investment rate mechanism. Tobin (1965) argued that there is a positive impact of inflation on growth through capital accumulation (lower marginal productivity of capital and real interest rates). In the presence of inflation, investors face lower returns on monetary assets relative to real assets (physical capital). Benhabib and Spiegel (2009) provide evidence that inflation positively affects growth below a 5\% price threshold level.

Employment and output growth are closely connected through the productivity-wage mechanism (Scott, McKean 1964). Output growth followed by sharp increase in the wage rates (above productivity rate) results in profitably fall and increasing unemployment in the long run. Okun (1962) documented a negative relationship between changes in the unemployment rate and output growth. Lee (2000) finds empirical support for Okun's law in most OECD countries. Malley and Molana (2008) report a threshold effect in the unemployment rate. Eriksson (1997) finds a trade-off between unemployment and long-run growth in the steady state. Dhont and Heylen (2008) suggest that differences in employment and output in Europe and the US arise from differences in the structure of fiscal policy. Other studies trying to explain movements in (un)employment and prices include Phelps (1967, 1968), Berentsen et al. (2011), Ericsson and Tryon (2001), Fernandez Valdovinos (2003), Barro (1996), Mollick et al. (2011). Monetary aggregates could also have an important role as explored in Bozoklu (2013). Oil passthrough effect as in Çatik and Karaçuka (2012) validates hypothesis of low inflationary environment associated with low pass-through. The series also show long memory behavior (Škare, Stjepanović 2013). Oil prices shocks and associated monetary policy response exhibits different influence on price and output fluctuations (Semko 2013).

The layout of the paper is as follows. Section 1 describes the data and the econometric framework. Section 2 presents the empirical results. Section 3 summarises the main findings and discusses their implications for successful macroeconomic policy design. 


\section{The model and data}

\subsection{Data}

Our dataset is a balanced panel with annual data on employment, prices and output from 1970 to 2010 for 119 countries $^{1}$. The variables are in annual percentage changes. The data sources are the USDA International macroeconomic dataset (historical data files) and the Conference board total economy database 2011.

\subsection{The model}

We investigate the relationship between $y_{i t}$, the annual growth rate of real output in country $i$ and year $t ; p_{i t}$, the annual inflation rate, and $e_{i t}$, the annual growth rate of employment, estimating the following model:

$$
\ln y_{i t}=\beta_{0 i}+\beta_{1 i} \ln p_{i t}+\beta_{2 i} \ln e_{i t}+u_{i t},
$$

where $u_{i t}$ is the error term.

To check the stationarity of the series in the panel under cross-sectional dependence we use first- and second-generation unit root tests. First-generation panel unit roots tests include Levin and Lin (1993), Levin et al. (2002), Harris and Tzavalis (1999), Im et al. (2003), Maddala and Wu (1999), Choi (2002, 2001), Hadri (2000) whilst secondgeneration tests are those of Bai and $\mathrm{Ng}(2001,2004)$, Moon and Perron (2004), Phillips and Sul (2003), Pesaran (2004, 2007), Breitung and Das (2005).

We find evidence of both stationary and non-stationary individual country series; overall, the results are inconclusive. This is not surprising, given the well-known low power of such tests (Breuer et al. 2002; Westerlund 2008). However, when using Baum's (2001) version of Hadri's test the null of stationarity in our panel is rejected at the $1 \%$ level under homoscedastic, heteroscedastic and serial dependence assumptions ${ }^{2}$. This residual-based Lagrange multiplier test is more powerful in large samples and with trend

\footnotetext{
${ }^{1}$ The countries included in the panel are the following: Albania, Algeria, Angola, Argentina, Armenia, Australia, Austria, Azerbaijan, Bahrain, Bangladesh, Barbados, Belarus, Belgium, Bosna and Hercegovina, Brazil, Bulgaria, Burkina Faso, Cambodia, Cameron, Canada, Central African Republic, Chile, China, Colombia, Congo, Democratic Republic of Costa Rica, Cote d'Ivore, Croatia, Cyprus, Czech Republic, Denmark, Ecuador, Egypt, Estonia, Ethiopia, Finland, France, Georgia, Germany, Ghana, Greece, Guatemala, Hungary, Iceland, India, Indonesia, Iran, Iraq, Ireland, Israel, Italy, Jamaica, Japan, Jordan, Kazakhstan, Kenya, Korea South, Kuwait, Kyrgyzstan, Latvia, Lithuania, Luxembourg, Macedonia, Madagascar, Malawi, Malaysia, Mali, Malta, Mexico, Moldova, Morocco, Mozambique, Myanmar, The Netherlands, New Zealand, Niger, Nigeria, Norway, Oman, Pakistan, Peru, The Philippines, Poland, Portugal, Romania, Russia, St.Lucia, Saudi Arabia, Senegal, Serbia, Singapore, Slovakia, Slovenia, South Africa, Spain, Sri Lanka, Sudan, Sweden, Switzerland, Syria, Taiwan, Tajikistan, Tanzania, Thailand, Trinidad and Tobago, Tunisia, Turkey, Turkmenistan, Uganda, Ukraine, United Arab Emirates, The United Kingdom, USA, Uruguay, Uzbekistan, Venezuela, Vietnam, Yemen, Zambia.

${ }^{2}$ Wagner and Hlouskova (2006) showed that Hadri's test tends to reject stationarity most of the times in the presence of autocorrelation. Baum (2001) proposed a more powerful version of this test (under the null that the error process is homoscedastic across the panel or heteroscedastic across countries and there is serial dependence in the disturbances).
} 
inclusion, therefore we carry out the remainder of the analysis under the maintained hypothesis that that series are generated by non-stationary stochastic processes.

In order to test if the series are cointegrated in the presence of heterogeneity in the panel, we use the Nyblom and Harvey (2000), Maddala and Wu (1999), Johansen (1995), Pedroni (2001), Persyn and Westerlund (2008) and Kao (1999) cointegration tests. The lag length was chosen on the basis of the Akaike information criterion (AIC) with individual intercepts and trends. Test results strongly reject the null of no cointegration in favour of the existence of a long-run equilibrium relationship between employment growth, inflation and output growth in the panel.

Having established cointegration, we estimate (1) using the FMOLS (fully modified OLS), DOLS (dynamic OLS), PMGE (pooled mean group estimator), MG (mean group) and DFE (dynamic fixed effect) methods. Following Pedroni (2001), the FMOLS estimator corrected for heterogeneity (with fixed effects) and the OLS estimator adjusted for serial correlation take the form:

$$
\hat{\beta}_{N T}^{*}-\beta=\left(\sum_{i=1}^{N} \hat{L}_{22 i}^{-2} \sum_{t=1}^{T}\left(x_{i t}-\bar{x}_{i}\right)^{2}\right)^{-1} \sum_{i=1}^{N} \hat{L}_{11 i}^{-1} \hat{L}_{22 i}^{-1}\left(\sum_{i=1}^{T}\left(x_{i t}-\bar{x}_{i}\right) \mu_{i t}^{*}-T \hat{\gamma}_{i}\right),
$$

where $\hat{L}_{i}$ is a lower triangular decomposition of the covariance matrix $\Omega_{\mathrm{I}}, \Gamma_{\mathrm{I}}$ a weighted sum of autocovariances, with $\hat{L}_{11 i}=\left(\Omega_{11 i}-\Omega_{21 i}^{2} / \Omega_{22 i}\right)^{1 / 2}$ and $L_{22 i}=\Omega_{22 i}^{1 / 2}$ being the long-run standard errors of the conditional process. Here $\hat{\beta}_{N T}$ is a fully modified estimator (FMOLS) with the individual specific mean of the form:

$$
\mu_{i t}^{*}=\mu_{i t}-\frac{\hat{L}_{21 i}}{\hat{L}_{22 i}} \Delta x_{i t}, \hat{\gamma}_{i} \equiv \hat{\Gamma}_{21 i}+\hat{\Omega}_{21 i}^{o}-\frac{\hat{L}_{21 i}}{\hat{L}_{22 i}}\left(\hat{\Gamma}_{22 i}+\Omega_{22 i}^{o}\right) .
$$

Pedroni (2001) proposes a dynamic OLS estimator (DOLS) of the form:

$$
\hat{\beta}_{i, D O L S}=\left[N^{-1} \sum_{i=1}^{N}\left(\sum_{t=1}^{T} z_{i t} z_{i t}^{\prime}\right)^{-1}\left(\sum_{t=1}^{T} z_{i t} \bar{y}_{i t}\right)\right]_{1},
$$

where $z_{i t}$ is the $2(K+1) \times 1$ vector of regressors:

$$
z_{i t}=\left\{\left(x_{i t}-\bar{x}_{i}\right), \Delta x_{i t-K}, \ldots, \Delta x_{i t+K}\right\} ; \tilde{y}_{i t}=y_{i t}-\bar{y}_{i}
$$

correcting for endogeneity and serial correlation in the panel by including leads and lags of the differenced I(1) regressors. Following the approach of Pesaran and Smith (1995), and Pesaran et al. (1999) for nonstationary dynamic panels with heterogeneous parameters we estimate our dynamic panel using MG, PMGE and DFE in the form:

$$
\Delta y_{i t}=\phi\left(y_{i, t-1}-\phi_{i}^{\prime} X_{i t}\right)+\sum_{j=1}^{p-1} \lambda_{i j}^{*} \Delta y_{i, t-1}+\sum_{j=0}^{q-1} \delta_{i j}^{\prime *} \Delta X_{i, t-j}+\mu_{i}+\varepsilon_{i t} .
$$

Following Pesaran, Shin and Smith (1999) we estimate an ARDL(2,2,2) model:

$$
y_{i t}=\sum_{j=1}^{p} \lambda_{i j} y_{i, t-j}+\sum_{j=0}^{q} \delta_{i j}^{\prime} x_{i, t-j}+\gamma_{i}^{\prime} d_{t}+\varepsilon_{i t},
$$

where $i=1,2, \ldots, 119$ stands for the country; $t=1,2, \ldots, 41$ for the time period; $x_{i t}=$ $(k \times 1)$ and $d_{t}(s \times 1)$ for the vectors of explanatory variables (regressors). 
Re-parameterising (6) we obtain an error correction model of the form:

$$
\Delta y_{i t}=\phi_{i} y_{i, t-1}+\beta_{i}^{\prime} x_{i t}+\sum_{j=1}^{p-1} \lambda_{i j}^{*} \Delta y_{i, t-j}+\sum_{j=0}^{q-1} \delta_{i j}^{* \prime} \Delta x_{i, t-j}+\gamma_{i}^{\prime} d_{t}+\varepsilon_{i t},
$$

where $\phi_{i}=-\left(1-\sum_{j=1}^{p} \lambda_{i j}\right), \beta_{i}=\sum_{j=0}^{q} \delta_{i j}, \lambda_{i j}^{*}=-\sum_{m=j+1}^{p} \lambda_{i m}, j=1, \ldots, p-1$ and $\delta_{i j}^{*}=-\sum_{m=j+1}^{q} \delta_{i m}, j=1, \ldots, q-1, i=1, \ldots, N$.

As in Pedroni $(1999,2004)$ we estimate the long-run relationship as follows:

$$
y_{i, t}=\alpha_{i}+\delta_{i} t+\beta_{1 i} x_{1 i, t}+\beta_{2 i} x_{2 i, t}+\ldots+\beta_{M i} x_{M i, t}+e_{i, t}
$$

for $t=1, \ldots, T ; i=1, \ldots, N ; m=1, \ldots, M$ with $T$ being the number of observations (time), $N$ the number of individual countries in the panel and $M$ the number of regression variables. After estimating (7) and identifying the long-run relationships, we estimate a panel VECM model:

$$
\Delta y_{i t}=\theta_{1 i}+\lambda_{1 i} E C_{i, t-1}+\sum_{k=1}^{m} \theta_{11 i k} \Delta y_{i, t-k}+\sum_{k=1}^{m} \theta_{12 i k} \Delta p_{i, t-k}+\sum_{k=1}^{m} \theta_{13 i k} \Delta e_{i, t-k}+u_{1 i t}
$$

and then test for multivariate causality with lag length $\mathrm{m}(\mathrm{SIC}=2)$ to examine the direction (patterns) of causality between the variables in both the short and the long run.

Multivariate causality as in Engle and Granger (1987) is tested by means of Wald tests (see Table 1) of the null $H_{0}: \theta_{12 i k}, \theta_{13 i k}=0, H_{0}: \theta_{22 i k}, \theta_{23 i k}=0, H_{0}: \theta_{31 i k}, \theta_{32 i k}=0$ (i.e., the independent variables do not cause the dependent ones in the model) for all $i$ and $k$ in (9). To examine the long-run relationship between independent and dependent variables we test $H_{0}: \lambda_{1 i}, \lambda_{2 i}, \lambda_{3 i}=0$ for all $i$ and $k$ in (9) (i.e., no long-run stable relationship between independent and dependent variables in the model).

\section{Empirical results}

In this section, we report the results of the PMGE, MG, FMOLS, DOLS, Dynamic Fixed Effect and VECM estimation as well as the results of the multivariate Granger causality analysis.

\subsection{Panel analysis results}

The empirical evidence clearly supports the existence of a long-run relationship between employment growth, inflation and output growth in the panel. This is confirmed by several estimation procedures. The panel results (not presented here) based on the FMOLS and DOLS tests for cointegration in heterogeneous panels as well as the Pedroni approach imply that the null $H_{0}: \beta_{\mathrm{i}}=0$ of no cointegration between the three variables is rejected both at individual country and panel level, except for Malta (FMOLS does not reject, DOLS reject), Norway, St. Lucia, Ukraine (both FMOLS and DOLS do not reject). The panel FMOLS and DOLS results without time dummies with $t$-statistic $=$ -1589.83 for FMOLS and -1368.77 for DOLS and with time dummies with $t$-statistic $=$ 
-2722.07 FMOLS and -2141.17 for DOLS strongly support the hypothesis of cointegration.

The fully modified OLS estimates of the cointegration relationship are reported in Table 2. In the case of the panel FMOLS and DOLS (without time trend) analysis the estimated coefficient for inflation is 0.0253 and 0.0294 respectively and is statistically significant in both cases, although with a positive effect on output growth. Panel unit root tests show that the series in the panel share common stochastic trends, and, therefore, omitting the trend component would generate a bias in both the FMOLS and DOLS estimates. With the inclusion of a time trend, the estimated impact of inflation on output growth is, as expected, negative (FMOLS: -0.0087; DOLS: -0.0091) and statistically significant at the $1 \%$ level. The panel long-run coefficient estimates using MGE and DFE are statistically significant with values for inflation of -0.023 (PMGE) and -0.027 (DFE) respectively, supporting the idea that inflation has a minor (close to zero) negative effect on output growth. The long-run coefficient for inflation using MGE is not statistically significant. Employment growth (without a time trend) has a positive effect (FMOLS $=0.3469$ and DOLS $=0.0968$ ) on output growth that is statistically significant at the $1 \%$ level. Its impact on output growth (with a time trend included) is also statistically significant and positive (even larger, with the FMOLS estimate equal to 0.4592 and the DOLS one to 0.3528 ). Employment growth has a positive and statistically significant impact on output growth at the individual country level (for 85 countries) with coefficient values ranging from 0.000 to 2.217 (Russia). The Hausman test statistic for choosing between the PMGE and MGE estimators is equal to 3.43, indicating that PMGE is to be preferred as being more efficient under the null that the long-run coefficients are homogenous. Results show that the PMGE long-run coefficients are in fact statistically significant at the individual country level for both inflation and employment growth. The latter affects output growth positively with statistically significant coefficients of 0.4431 for PMGE and 0.5227 for DFE. The panel VECM results do not differ substantially from the PMGE, MGE, DFE, FMOLS and DOLS ones, with the estimated long-run coefficients being -0.0012 for inflation and 0.3001 for employment growth (all statistically significant at the $1 \%$ level).

Overall, the long-run coefficients for inflation and employment growth converge to the PMGE values of -0.002 and 0.443 respectively. This is an important finding for two reasons. First, it supports empirically the existence of a long-run relationship between employment growth, inflation and output growth as postulated by Phillips (1962). Second, it provides policy-makers with an estimate of the inflation and employment growth effects on output growth. The cointegration results appear to be very robust. For instance, the estimates from the error correction equations (9) indicate that $\lambda$ is statistically significant and negative for all countries in the panel. The same holds for the panel VECM as can be seen from Table 2 (except for the positive values of $\lambda$ when (p) is the dependent variable). This confirms the existence of a long-run relationship between the three variables. 
Table 1. Wald F-test results from panel VECM

\begin{tabular}{|c|c|c|c|c|c|c|c|c|c|}
\hline \multirow[t]{2}{*}{$\begin{array}{c}\text { Dependent } \\
\text { variable }\end{array}$} & \multicolumn{3}{|c|}{$(\Delta y)$} & \multicolumn{3}{|c|}{$(\Delta p)$} & \multicolumn{3}{|c|}{$(\Delta e)$} \\
\hline & $\mathrm{SR}$ & LR & JR & $\mathrm{SR}$ & LR & $\mathrm{JR}$ & SR & LR & JR \\
\hline$($ constant $)$ & \multicolumn{3}{|c|}{$3.0866 * * *$} & \multicolumn{3}{|c|}{-54.983} & \multicolumn{3}{|c|}{$0.2590 * * *$} \\
\hline$\left(\Delta y_{t-1}\right)$ & \multicolumn{3}{|c|}{$-0.1356^{* * *}$} & \multicolumn{3}{|c|}{$-9.7825^{* *}$} & \multicolumn{3}{|c|}{$0.0850 * *$} \\
\hline$\left(\Delta y_{t-2}\right)$ & \multicolumn{3}{|c|}{$-0.0537 * * *$} & \multicolumn{3}{|c|}{$-10.563 * * *$} & \multicolumn{3}{|c|}{$0.0230 * *$} \\
\hline$\left(\Delta p_{t-1}\right)$ & \multicolumn{3}{|c|}{$-0.0012 * * *$} & \multicolumn{3}{|c|}{$-0.4073 * *$} & \multicolumn{3}{|c|}{-0.0000} \\
\hline$\left(\Delta p_{t-2}\right)$ & \multicolumn{3}{|c|}{$-0.0009 * *$} & \multicolumn{3}{|c|}{$-0.2550 * *$} & \multicolumn{3}{|c|}{-0.0000} \\
\hline$\left(\Delta e_{t-1}\right)$ & \multicolumn{3}{|c|}{$0.3001 * * *$} & \multicolumn{3}{|c|}{$-8.6596^{* *}$} & \multicolumn{3}{|c|}{$-0.6149 * * *$} \\
\hline$\left(\Delta e_{t-2}\right)$ & \multicolumn{3}{|c|}{$0.0961^{* *}$} & \multicolumn{3}{|c|}{$-14.272 * *$} & \multicolumn{3}{|c|}{$-0.2736^{* * *}$} \\
\hline$\left(E C_{t-1}\right)$ & \multicolumn{3}{|c|}{$-0.4392 * * *$} & \multicolumn{3}{|c|}{$7.4018 * *$} & \multicolumn{3}{|c|}{$-0.0440 * *$} \\
\hline & \multicolumn{3}{|c|}{$p \rightarrow y$} & \multicolumn{3}{|c|}{$y \rightarrow p$} & \multicolumn{3}{|c|}{$y \rightarrow e$} \\
\hline & $\begin{array}{l}31.1 \\
* * *\end{array}$ & $\begin{array}{c}-29.3 \\
* * *\end{array}$ & $\begin{array}{c}287.3 \\
* * *\end{array}$ & $\begin{array}{l}50.2 \\
* * *\end{array}$ & $\begin{array}{c}6.31 \\
* *\end{array}$ & $\begin{array}{l}34.2 \\
* * *\end{array}$ & $\begin{array}{l}52.4 \\
* * *\end{array}$ & $\begin{array}{c}-5.65 \\
* * \\
\end{array}$ & $\begin{array}{l}35.0 \\
* * *\end{array}$ \\
\hline Causality directions & \multicolumn{3}{|c|}{$e \rightarrow y$} & \multicolumn{3}{|c|}{$e \rightarrow p$} & \multicolumn{3}{|c|}{$p \rightarrow e$} \\
\hline & $\begin{array}{l}59.4 \\
* * * \\
\end{array}$ & $\begin{array}{c}-29.3 \\
* * * \\
\end{array}$ & $\begin{array}{c}303.0 \\
* * *\end{array}$ & $\begin{array}{l}21.0 \\
* * *\end{array}$ & $\begin{array}{c}6.31 \\
* * \\
\end{array}$ & $\begin{array}{l}24.1 \\
* * * \\
\end{array}$ & 0.48 & $\begin{array}{c}-5.65 \\
* * \\
\end{array}$ & $\begin{array}{l}12.3 \\
* * * \\
\end{array}$ \\
\hline
\end{tabular}

Notes: LR, SR, JR and EC stand for long-run, short-run, and joint (both short- and long-run) causality and error-correction coefficients respectively; $y \rightarrow p$ means that variable $y$ does not Granger cause variable $p$ (null hypothesis); ${ }^{* *},{ }^{* *}$ and $*$ represent significance at $1 \%, 5 \%$ and $10 \%$ respectively.

Table 2. Panel short- and long-run coefficients (dependent variable $\Delta y$ )

\begin{tabular}{|c|c|c|c|c|c|}
\hline & PMGE & MGE & FMOLS & DOLS & DFE \\
\hline & \multicolumn{5}{|c|}{ with time trend } \\
\hline \multicolumn{6}{|l|}{ Long-run coefficients } \\
\hline$(p)$ & $-0.002 * * *$ & -0.002 & $0.025^{* *}$ & $0.029 * *$ & $-0.002 * *$ \\
\hline$(e)$ & $0.443 * * *$ & 0.212 & $0.346^{* * *}$ & $0.096 * * *$ & $0.522 * *$ \\
\hline Error correction & $-0.664 * *$ & $-0.770 * *$ & & & $-0.662 * *$ \\
\hline \multicolumn{6}{|l|}{ Short-run coefficients } \\
\hline$(\Delta p)$ & -0.001 & 0.000 & & & -0.000 \\
\hline$(\Delta e)$ & -0.326 & -0.271 & & & -0.053 \\
\hline constant & $1.840 * * *$ & $2.822 * * *$ & & & $1.732 * *$ \\
\hline Long-run coefficients & \multicolumn{5}{|c|}{ with time trend } \\
\hline$(\Delta p)$ & & & $-0.008^{* * *}$ & $-0.009^{* * *}$ & \\
\hline$(\Delta e)$ & & & $0.459 * * *$ & $0.352 * * *$ & \\
\hline
\end{tabular}

Hausman test

$3.43(0.1798)$

Notes: $* * *, * *$ and $*$ represent significance at $1 \%, 5 \%$ and $10 \%$ respectively. For short/long-run coefficients (empirical results of this study) on a national level (for any individual country from 119 investigated here) please contact corresponding author. Empirical results for individual countries are not presented here due to space constraints. 


\subsection{Does inflation matters for growth? - Individual country analysis}

Our results are in line with the "threshold level" inflation effect on growth evidenced in Sarel (1996), Ghosh and Phillips (1998), Benhabib and Spiegel (2009) and Gillman and Kejak (2005). The panel results in Table 2 show that the impact of inflation on growth in the short and long run is negative and very close to zero, almost negligible. The results of cointegration analysis for individual countries vary greatly from the results obtained from panel cointegration analysis for the entire panel (all countries). Phelps' contention $(1967,1968)$ that the rate of unemployment in the long run could not be changed by monetary and fiscal policy through aggregate demand is only partially supported by our findings. In countries with developed financial markets and with lower exchange rate volatility, moderate inflation (up to $9 \%$ ) has a significant positive impact on economic growth. This is particularly evident in the Scandinavian countries and Germany. In these countries, an increase in the price level of $10 \%$ is associated with an increase in production in the range $2-5 \%$. The biggest positive impact of a moderate inflation rate on economic growth is recorded in Germany. In stable developed economies with strong financial markets, inflation below $9 \%$ has no negative impact on financial markets. In these countries, inflation also has no adverse impact on the rate of return, investment and economic growth. Investors perceive these countries as "safe investment zones" and a moderate inflation rate (9\%) encourages capital accumulation, investment and thus economic growth. In Norway, Germany, the Netherlands and Sweden inflation has a positive impact on output and employment growth. These results support the hypothesis that policy-generated inflation can reduce unemployment significantly in the long run.

Similar effects are found in countries with oil resources where supply shocks driven by oil price increases lead to higher growth (through capital accumulation and investment) and lower unemployment in the long run. The empirical results confirm this for Saudi Arabia, Morocco, and United Arab Emirates. In other Middle East and Africa oil producing nations, negative inflation-growth relationship exists because of different monetary policy regimes, inflation uncertainty, economy structure and market openness and government interventions on prices.

In small and open economies such as Belgium, Austria, Croatia, Cameroon, Trinidad and Tobago, Jordan, Malta and large ones such as France, Central African Republic, China, Italy and Japan there is a moderate positive impact of inflation on economic growth achieved through depreciation and higher exports (especially in the EU area). The cointegration coefficients in these countries range between 0.1 and 0.5 , which means that a $10 \%$ increase in prices increases growth by $1-5 \%$ through higher exports.

These results are consistent with those of Lucas (1973), Mallik and Chowdhury (2001), Gillman and Kejak (2002) who report a positive relationship between inflation and economic growth.

For the vast majority of countries ( 90 of them), the long-run impact of inflation on growth is negligible, as also in Arai et al. (2004). The exceptions are countries such as Greece, Hungary, Kenya, Kuwait, Luxemburg, Slovakia, South Africa, the US. This might reflect other factors such as the degree of financial market development, market 
uncertainty, exchange rate and balance of payment policy, labour productivity, risk aversion; these should be included in future research on the inflation-growth relationship.

The short-run dynamics between inflation and growth differ significantly across countries. The VECM estimates suggest a positive relation between inflation and growth in the short run for 15 countries including St. Lucia, Switzerland, Ireland, and Tunisia. Small-open economies can boost growth through a depreciation of the exchange rate but only for a limited time. For Malaysia, Singapore, Denmark, Germany, we find robust statistical evidence that inflation boosts growth in the short run. The overall conclusion is that inflation does not matter for growth in the short run.

The long-run error adjustment coefficients are statistically significant in the PMGE, MG and VECM models (results available at request from the corresponding author), and suggest that the adjustment toward a long-run equilibrium level is fairly quick. The speed of adjustment to equilibrium is, as expected, lower in countries with less efficient central banking system (Azerbaijan, Georgia, Guatemala, Tanzania, Yemen), where the adjustment takes around three years, compared to 1.8 years in France and 1.5 years in the US. In countries characterised by trade openness (Central African Republic, South Korea, India, Syria, Senegal, St. Lucia, Tunisia, Turkey, Taiwan, Zambia, Algeria, Australia, Czech Republic) the adjustment to equilibrium (through the exchange rate) is even quicker - approximately 0.99 year to 0.71 year. In countries with large service sector share in output, massive FDI inflows and favorable trade openness regime (low tariffs and trade barriers, foreign exchange control) equilibrium adjustments are much more rapid. Growth-factor accumulation-productivity-innovation mechanism works better in open economies as found by Srinivasan (2001), so open economies quickly adapt to long-run equilibrium.

\subsection{Does employment matter for growth? Individual country analysis}

As in Verdoorn (1993) we find that a higher rate of growth is associated to higher employment growth. However, the impact of employment growth on output growth differs considerable across countries as a result of differences in labour markets (flexibility) and productivity. Employment growth has a positive and statistically significant effect on output growth in 68 countries in the panel (in the sense that at least two from a set of panel cointegration models have positive and statistically significant long-run coefficients), with the estimated long-run coefficient ranging from 0.028 to 2.150. Some countries, such as Russia, experienced high growth as a consequence of an increase in the labour supply (hours worked) and increased labour market efficiency. In Russia, the impact of employment growth on output growth (the growth-employment elasticity) was on average $2.214 \%$. In fact, to calculate the "net" impact of employment growth on output growth one should correct the long-run multiplier for productivity changes. In the case of Russia, faster employment growth leads to faster output growth through faster growth in total productivity, as in Verdoorn's law.

The same pattern is observed in the Czech Republic, Denmark and the US. On the other hand, countries such as Cameron and Congo exhibit a negative long-run relationship between employment and output growth. The reason is the very low growth in total 
productivity growth (between 0 and 1\%). Countries with increasing returns to scale (such as the US, Denmark and Russia) experience high growth rates associated with employment growth. Other countries, such as Czech Republic, achieve higher output growth rates as a consequence of improved labour market allocation and better firm organisation. Employment growth (1\%) in Cameron is associated with a fall in output growth in Cameroon and Congo ( $-5 \%$ and $-4 \%$ respectively) as a result of rigidities in the labour market (Congo had the highest rigidity of employment index in 2006) or decreasing returns to scale (as in Cameroon, where $70 \%$ of the labour force is employed in agriculture). The differences in the results for other Sub-Saharan African countries with low TFP growth rate are due to differences in capital productivity (average age), labor productivity (average level of education) between Sub-Saharan African countries (capital stock, capital output and capital labor ratios).

The cointegration coefficients support Verdoorn's law in countries with positive multifactor productivity where higher employment growth leads to higher output growth. Developed countries with some degree of rigidity in labour markets (leading to increase in the youth unemployment) experience slower output growth associated with employment growth (France is a good example, the long-run coefficient being equal to 0.140).

In the short run, for 28 countries we find a (statistically significant) positive but rather small employment impact multiplier value. The estimated speed of the adjustment coefficients (feedback mechanism) has the expected negative sign, with differences across countries. In countries with rigid labour markets and low multifactor productivity the adjustment is slower, lasting on average 1.8 years. In the presence of more flexible labour markets convergence is instead achieved within a year. The case of India is particularly interesting. Here the growth-employment cointegration coefficient is negative because its economy is approaching full employment. India achieves fast growing rates thanks to the high-productivity growth associated to the low employment growth. Because of rapid structural changes in its economy and the increase in the labour-force participation rate, it faces "jobless growth". This is why it converges speedily to its long-run equilibrium (within one year on average).

\subsection{Granger causality analysis for inflation, employment growth and output growth}

Having already found long-run causality (as implied by the EC coefficients) we are also interested in examining the direction of causality between the variables (see Table 1).

It can be seen that the estimates of equation (9) imply bidirectional (and statistically significant at the $1 \%$ level) Granger causality between inflation and output growth $(p \rightarrow y$, $y \rightarrow p)$, and employment growth and output growth as well as inflation $(e \rightarrow y, y \rightarrow e$, $e \rightarrow p, p \rightarrow e$ ) in both the short and long run. The only exception is the unidirectional short-run causality running from inflation to output growth $(p \rightarrow y)$. This is consistent with Phillips' idea that employment growth, inflation and output growth are both policy instruments and targets driven by some kind of mutually self-reinforcing process (bidirectional causality). 
Granger causality analysis provides clear evidence that employment growth is an important determinant of output growth in the short and long run. Output growth also Granger causes employment growth in the short and long run implying bidirectional Granger causality between employment and output growth. Employment has a positive but small short-run impact on output growth. This is because higher productivity growth boosts long-run growth. In the short run, employment growth Granger cause output growth. In the long run, productivity growth exceeds employment growth reducing the impact of employment growth on output growth (negative Granger causality). As long as employment growth is accompanied by an adequate change in multifactor productivity employment growth Granger causes output growth. Overall, the panel Granger causality analysis shows that employment is an important determinant of output growth and vice versa both in the short and long run.

Inflation positively Granger causes employment in the short run, confirming the idea of a beneficial short-run impact. Employment growth in turn has a positive effect on output growth in the short run. We find negative Granger causality running from inflation to employment in the long run, which is the result of inflation uncertainty. Bidirectional Granger causality between inflation and employment growth exists in the longrun. Long-run employment growth Granger causes inflation positively. Unidirectional Granger causality from employment growth to inflation is present in the short run. On the basis of the results of the panel Granger analysis, we can conclude that inflation in the short run has no influence on changes in employment. In the long run, changes in inflation negatively affect employment growth as a result of the long-run negative impact of inflation on output growth. Bidirectional Granger causality is found in the both the short and the long run between inflation and output growth ${ }^{3}$.

\section{Conclusions}

The evidence presented in this paper based on cointegration and Granger causality tests carried out for a panel including 119 countries indicates that inflation and employment growth do matter for output growth. However, there are cross-country differences that can be rationalised in terms of differences in labour markets, productivity, policy targeting, economy structure and institutional development. Future research should consider such variables explicitly to identify the exact nature of the channels through which inflation and employment growth affect output growth. Also, possible thresholds effects and nonlinearities should be investigated. Nevertheless, our results are of importance to policy makers since, as already stressed, knowledge of the dynamic relationships between the variables examined is essential for the purpose of designing appropriate policies.

\footnotetext{
${ }^{3}$ Caporale and Škare (2011) carry out Granger tests for individual countries rather than a panel as in the present study.
} 


\section{References}

Arai, M.; Kinnwall, M.; Thoursie, P. S. 2004. Cyclical and causal patterns of inflation and GDP growth, Applied Economics 36(15): 1705-1715. http://dx.doi.org/10.1080/0003684042000266874 Benhabib, J.; Spiegel, M. M. 2009. Moderate inflation and the deflation-depression link, Journal of Money, Credit and Banking 41(4): 787-798. http://dx.doi.org/10.1111/j.1538-4616.2009.00232.x

Bai, J.; Ng, S. 2001. A consistent test for conditional symmetry in time series models, Journal of Econometrics 103(1-2): 225-258. http://dx.doi.org/10.1016/S0304-4076(01)00044-6

Bai, J.; Ng, S. 2004. A panic attack on unit roots and cointegration, Econometrica 72(4): 11271177. http://dx.doi.org/10.1111/j.1468-0262.2004.00528.x

Barro, R. J. 1996. Inflation and growth, Journal of Money, Credit and Banking 1(3): 153-169. Ohio State University Press. http://dx.doi.org/10.2307/1991196

Baum, C. F. 2001. HADRILM: Stata module to perform Hadri panel unit root test, Statistical Software Components No. S419701. Boston College Department of Economics.

Berentsen, B. A.; Menzio, G.; Wright, R. 2011. Inflation and unemployment in the long run, American Economic Review 101: 371-398. http://dx.doi.org/10.1257/aer.101.1.371

Blanchard, O. J.; Fischer, S. 1989. Lectures on macroeconomics. USA, Cambridge: MIT press. $650 \mathrm{p}$.

Bozoklu, S. 2013. Money, income, and causality: an examination for the Turkish economy, Ekonomska istraživanja - Economic Research 26(1): 171-182.

Breitung, J.; Das, S. 2005. Panel unit root tests under cross-sectional dependence, Statistica Neerlandica 59(4): 414-433. http://dx.doi.org/10.1111/j.1467-9574.2005.00299.x

Breuer, J. B.; McNown, R.; Wallace, M. 2002. Series specific unit root tests with panel data, Oxford Bulletin of Economics and Statistics 64(5): 527-546.

http://dx.doi.org/10.1111/1468-0084.00276

Bruno, M.; Easterly, W. 1996. Inflation and growth: in search of a stable relationship, Review 72. Federal Reserve Bank of St. Louis.

Bruno, M.; Easterly, W. 1998. Inflation crises and long-run growth, Journal of Monetary Economics 41(1): 3-26. http://dx.doi.org/10.1016/S0304-3932(97)00063-9

Burdekin, R.; Denzau, A.; Keil, M.; Sitthiyot, T.; Willett, T. 2004. When does inflation hurt economic growth? Different nonlinearities for different economies, Journal of Macroeconomics 26(3): 519-532. http://dx.doi.org/10.1016/j.jmacro.2003.03.005

Caporale, G. M.; Škare, M. 2011. Short-and long-run linkages between employment growth, inflation and output growth: evidence from a large panel, Brunel University Working Paper.

Çatik, A. N.; Karaçuka, M. 2012. Oil pass-through to domestic prices in Turkey: does the change in inflation regime matter?, Economic Research - Ekonomska Istraživanja 25(2): 277-296.

Choi, I. 2001. Unit root test for panel data, Journal of International Money and Finance 20: 249-272. http://dx.doi.org/10.1016/S0261-5606(00)00048-6

Choi, I. 2002. Combination unit root tests for cross-sectionally correlated pannels. Mimeo: Hong Kong University of Science and Technology.

Dhont, T.; Heylen, F. 2008. Employment and growth in Europe and the US - the role of fiscal policy composition, Oxford Economic Papers 61(3): 538-565. http://dx.doi.org/10.1093/oep/gpn034

Engle, R. F.; Granger, C. W. J. 1987. Co-integration and error correction: representation, estimation, and testing, Econometrica 55(2): 251-276. http://dx.doi.org/10.2307/1913236

Ericsson, N. R.; Tryon, R. W. 2001. Output and inflation in the long run, Journal of Applied Econometrics 16(3) 241-253. http://dx.doi.org/10.1002/jae.614 
Eriksson, C. 1997. Is there a trade-off between employment and growth?, Oxford Economic Papers 49(1): 77-88. http://dx.doi.org/10.1093/oxfordjournals.oep.a028598

Fernandez Valdovinos, C. 2003. Inflation and economic growth in the long run, Economics Letters 80(2): 167-173. http://dx.doi.org/10.1016/S0165-1765(03)00085-5

Ghosh, A.; Phillips, S. 1998. Inflation, disinflation, and growth, International Monetary Fund Staff Papers 454(4).

Gillman, M.; Kejak, M. 2002. Modeling the effect of inflation: growth, levels, and Tobin, in Proceedings of the 2002 North American Summer Meetings of the Econometric Society, June 20-24, 2002, Los Angeles.

Gillman, M.; Kejak, M. 2005. Contrasting models of the effect of inflation on growth, Journal of Economic Surveys 19(1): 113-136. Wiley Online Library.

http://dx.doi.org/10.1111/j.0950-0804.2005.00241.x

Hadri, K. 2000. Testing for stationarity in heterogeneous panel data, The Econometrics Journal 3(2): 148-161.

Harris, R. D. F.; Tzavalis, E. 1999. Inference for unit roots in dynamic panels where the time dimension is fixed, Journal of Econometrics 91(2): 201-226.

http://dx.doi.org/10.1111/1368-423X.00043

Im, K. S.; Pesaran, M. H.; Shin, Y. 2003. Testing for unit roots in heterogeneous panels, Journal of Econometrics 115(1): 53-74. http://dx.doi.org/10.1016/S0304-4076(03)00092-7

Johansen, S. 1995. Likelihood-based inference in cointegrated vector autoregressive models. USA: Oxford University Press. http://dx.doi.org/10.1093/0198774508.001.0001

Kao, C. 1999. Spurious regression and residual-based tests for cointegration in panel data, Journal of Econometrics 90(1): 1-44. http://dx.doi.org/10.1016/S0304-4076(98)00023-2

Lee, J. 2000. The robustness of Okun's law: evidence from OECD countries, Journal of Macroeconomics 22(2): 331-356. http://dx.doi.org/10.1016/S0164-0704(00)00135-X

Levin, A.; Lin, C. F. 1993. Unit root test in panel data: new results, Discussion Paper. University of California at San Diego.

Levin, A.; Lin, C. F.; Chu, C. S. J. 2002. Unit root tests in panel data: asymptotic and finitesample properties, Journal of Econometrics 108(1): 1-24.

http://dx.doi.org/10.1016/S0304-4076(01)00098-7

López-Villavicencio, A.; Mignon, V. 2011. On the impact of inflation on output growth: does the level of inflation matter?, Journal of Macroeconomics 33(3): 455-464.

http://dx.doi.org/10.1016/j.jmacro.2011.02.003

Lucas, R. E. 1973. Some international evidence on output-inflation tradeoffs, The American Economic Review 63(3): 326-334.

Maddala, G. S.; Wu, S. 1999. A comparative study of unit root test with panel data and a new simple test, Oxford Bulletin of Economics and Statistics 61: 631-652.

http://dx.doi.org/10.1111/1468-0084.61.s1.13

Malley, J.; Molana, H. 2008. Output, unemployment and Okun's law: some evidence from the G7, Economics Letters 101(2): 113-115. http://dx.doi.org/10.1016/j.econlet.2008.06.013

Mallik, G.; Chowdhury, A. 2001. Inflation and economic growth: evidence from four south Asian countries, Asia-Pacific Development Journal 8(1): 123-135.

Mollick, A. V.; Cabral, R.; Carneiro, F. G. 2011. Does inflation targeting matter for output growth?, Journal of Policy Modeling 33: 537-551. http://dx.doi.org/10.1016/j.jpolmod.2011.03.010

Moon, H. R.; Perron, B. 2004. Testing for a unit root in panels with dynamic factors, Journal of Econometrics 122(1): 81-126. http://dx.doi.org/10.1016/j.jeconom.2003.10.020 
Nyblom, J.; Harvey, A. 2000. Tests of common stochastic trends, Econometric Theory 16(2): 176-199.

Okun, A. M. 1962. The gap between actual and potential output, in Proceedings of the American Statistical Association, reprinted in Edmund S. Phelps (Ed.). 1965. Problems of the modern economy. New York: Norton.

Pedroni, P. 1999. Critical values for cointegration tests in heterogeneous panels with multiple regressors, Oxford Bulletin of Economics and Statistics 61(S1): 653-670.

http://dx.doi.org/10.1111/1468-0084.61.s1.14

Pedroni, P. 2001. Purchasing power parity tests in cointegrated panels, Review of Economics and Statistics 83(4): 727-731. http://dx.doi.org/10.1162/003465301753237803

Pedroni, P. 2004. Panel cointegration: asymptotic and finite sample properties of pooled time series tests with an application to the PPP hypothesis, Econometric Theory 20(03): 597-625. http://dx.doi.org/10.1017/S0266466604203073

Persyn, D.; Westerlund, J. 2008. Error-correction-based cointegration tests for panel data, Stata Journal 8(2): 232-241.

Pesaran, M. H.; Smith, R. 1995. Estimating long-run relationships from dynamic heterogeneous panels, Journal of Econometrics 68(1): 79-113. http://dx.doi.org/10.1016/0304-4076(94)01644-F

Pesaran, M. H.; Shin, Y.; Smith, R. P. 1999. Pooled mean group estimation of dynamic heterogeneous panels, Journal of the American Statistical Association 94(446): 621-634.

http://dx.doi.org/10.1002/jae.951

Pesaran, M. H. 2007. A simple panel unit root test in the presence of cross section dependence, Journal of Applied Econometrics 22(2): 265-312.

Pesaran, M. H. 2004. General diagnostic tests for cross section dependence in panels, CESifo Working Paper Series No. 1229; IZA Discussion Paper No. 1240. University of Munchen, Wirtschaftsforschung Ifo-Institut, and CESifo. IZA.

Phelps, E S. 1967. Phillips curves, expectations of inflation and optimal unemployment over time, Economica 35(139): 254-281. http://dx.doi.org/10.2307/2552025

Phelps, E. S. 1968. Money-wage dynamics and labor-market equilibrium, Journal of Political Economy 76(4): 678-711. Chicago: The University of Chicago Press.

http://dx.doi.org/10.1086/259438

Phillips, A. W. 1958. The relation between unemployment and the rate of change of money wage rates in the United Kingdom, 1861-1957, Economica 25(100): 17.

Phillips, A. W. 1962. Employment, inflation and growth, Economica 29(113): 1-16.

http://dx.doi.org/10.1111/j.1468-0335.1962.tb00001.x

Phillips, P. C. B.; Sul, D. 2003. Dynamic panel estimation and homogeneity testing under cross section dependence, Econometrics Journal 6(1): 217-259.

http://dx.doi.org/10.1111/1368-423X.00108

Sarel, M. 1996. Nonlinear effects of inflation on economic growth, Staff Papers - International Monetary Fund (43)1: 199-215.

Scott, R. H.; McKean, J. 1964. A “cross section" look at employment, growth, and inflation, Economic Inquiry 3(1): 1-6. http://dx.doi.org/10.1111/j.1465-7295.1964.tb00899.x

Semko, R. 2013. Optimal economic policy and oil prices shocks in Russia, Ekonomska istraživanja - Economic Research 26(2): 69-82.

Srinivasan, T. N. 2001. Trade, development and growth, Essays in International Economics 225. Princeton, N. J. International Economics Section, Department of Economics, Princeton University. $38 \mathrm{p}$. 
Škare, M.; Stjepanović, S. 2013. A fractionally integrated model for the Croatian aggregate output (GDP) series, Ekonomska istraživanja - Economic Research 26(2): 289-330.

Tobin, J. 1965. Money and economic growth, Econometrica 33(4): 671-684. http://dx.doi.org/10.2307/1910352

Verdoorn, P. J. 1993. On the factors determining the growth of labour productivity, Italian Economic Papers 2: 59-68.

Wagner, M.; Hlouskova, J. 2009. The performance of panel cointegration methods: results from a large scale simulation study, Econometric Reviews 29(2): 182-223.

Westerlund, J. 2008. Essays on panel cointegration. Saarbrucken: VDM Verlag Dr. Mueller e.K. $208 \mathrm{p}$.

Guglielmo Maria CAPORALE. Professor of Economics and Finance and Director of the Centre for Empirical Finance at Brunel University, London. He is also a Visiting Professor at London South Bank University and London Metropolitan University, a Research Professor at DIW Berlin, a CESifo Research Network Fellow and an NCID (Navarra Center for International Development) Non-Resident Fellow. Prior to taking up his current position, he was a Research Officer at the National Institute of Economic and Social Research in London; a Research Fellow and then a Senior Research Fellow at the Centre for Economic Forecasting at the London Business School; Professor of Economics at the University of East London; Professor of Economics and Finance as well as Director of the Centre for Monetary and Financial Economics at London South Bank University.

Marinko ŠKARE. Professor of Economics, Economic Research Journal Editor-in-Chief, Member of Editorial Board of several international journals, Department Economics and Tourism "Dr. Mijo Mirković" in Pula, Juraj Dobrila University of Pula. He served as Assistant Dean for Education, Faculty of Economics \&Tourism, Pula, Assistant Dean for International Cooperation, Faculty of Economics $\&$ Tourism, Pula, Main and Team Researcher on several scientific projects, Former Dean of the Faculty of Economics \& Tourism, Pula and Former Vice President for International Cooperation, Juraj Dobrila University of Pula. He has published several books and a large number of scientific papers on the subject of economic growth, welfare economics and poverty, human capital, economics in transition, economic philosophy and monetary economics. He is a member of the American Economic Association, Royal Economic Society, Economic History Association, Economic History Society, and Association for Comparative Economic Studies. 